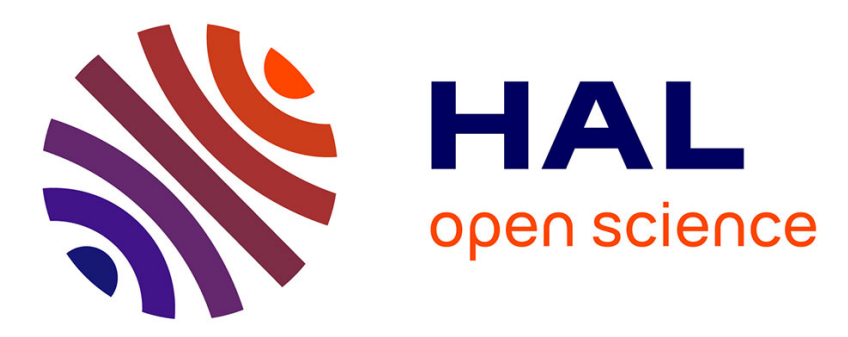

\title{
Preliminary study of the cecal bacterial flora in the pony: quantification and diet effect
}

\author{
Véronique Julliand, H Prevost, Jl Tisserand
}

\section{To cite this version:}

Véronique Julliand, H Prevost, Jl Tisserand. Preliminary study of the cecal bacterial flora in the pony: quantification and diet effect. Annales de zootechnie, 1993, 42 (2), pp.183-183. hal-00888917

\section{HAL Id: hal-00888917 https://hal.science/hal-00888917}

Submitted on 1 Jan 1993

HAL is a multi-disciplinary open access archive for the deposit and dissemination of scientific research documents, whether they are published or not. The documents may come from teaching and research institutions in France or abroad, or from public or private research centers.
L'archive ouverte pluridisciplinaire HAL, est destinée au dépôt et à la diffusion de documents scientifiques de niveau recherche, publiés ou non, émanant des établissements d'enseignement et de recherche français ou étrangers, des laboratoires publics ou privés. 


\title{
Preliminary study of the cecal bacterial flora in the pony: quantification and diet effect
}

\author{
V Julliand ${ }^{1}, \mathrm{H}$ Prevost ${ }^{2}$, JL Tisserand 1 \\ 1 INRA-ENSSAA, laboratoire associé de Recherches zootechniques, 21000 Dijon; \\ 2 ENSBANA, laboratoire de Microbiologie, 21000 Dijon, France
}

The objectives were to enumerate the cecal proteolytic and cellulolytic bacteria in the pony and assess the effect of different diets.

Five cecally fistulated ponies were used. Three animals were fed the 4 following diets: $77 \%$ wheat-straw $+15 \%$ maize $+8 \%$ soybean meal (D1); $78 \%$ wheat-straw $+22 \%$ maize (D2); $78 \%$ wheat-straw $+22 \%$ maize $+14 \mathrm{~g}$ urea per $\mathrm{kg}$ straw (D3); $100 \%$ wheat-straw (D4). The 5 ponies were fed $72 \%$ wheat-straw with molasses at $10 \%+18 \%$ maize $+10 \%$ soybean meal (D5); then $100 \%$ hay (D6). The diets were offered ad libitum at $8 \mathrm{am}$ and $4 \mathrm{pm}$. The ponies were adapted to each ration for a 2 wk period prior to cecal fluid collections.

Cecal fluid samples were collected immediately before the first meal in sterile $\mathrm{CO}_{2}$ saturated flasks. Flasks were maintained at $4^{\circ} \mathrm{C}$ and immediately transported to the laboratory. Half a $\mathrm{ml}$ of appropriate decimal dilutions were inoculated anaerobically into 5 roll tubes (Hungate, 1950) containing cellulotytic or proteolytic media (for 11:5 $\mathrm{g}$ cellulose MN 300 and $10 \mathrm{~g}$ casein respectively). Inoculated tubes were incubated for $7 \mathrm{~d}$ at $39^{\circ} \mathrm{C}$ and every colony was counted from rolltubes containing between 20-200 colonies.

Cellulolytic bacteria formed a higher proportion of the cecal microflora than proteolytic bacteria (except for D1). Mean counts of proteolytic bacteria were from 0.3 to 1.0 $\times 10^{6} \mathrm{CFU} / \mathrm{ml}$ (except for D1), in agreement with the results of Reitnour and Mitchell (1979). In ration D1, soybean meal might have stimulated proteolytic bacteria, although it did not in ration D5. Mean counts of cellulolytic bacteria were from 4.6 to $9.4 \times 10^{6} \mathrm{CFU} / \mathrm{ml}$, increasing but not significantly with the fiber proportion of the diet and with molasses. These results seem low for a herbivore cecum. Incomplete mastery of the anaerobic technique or of the substrates might be concerned.

Hungate RE (1950) Bacteriol Rev, 14, 1-63

Reitnour CM, Mitchell GE (1979) J Agric Sci

(Camb) 92, 507-509

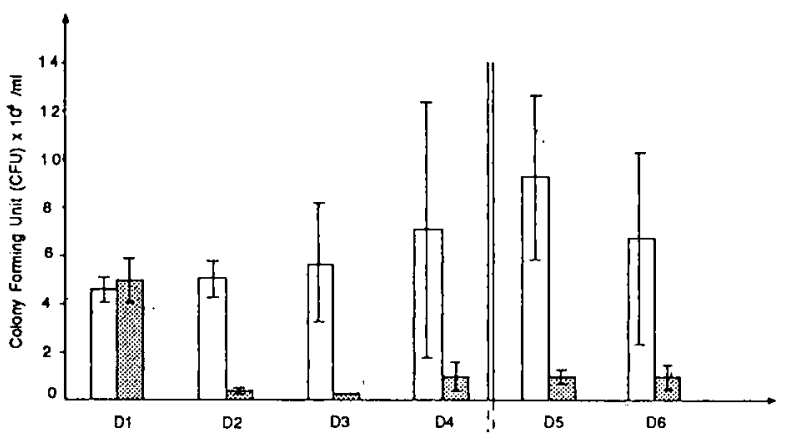

Fig 1. Diet effect on mean counts of cellulolytic $(\square)$ and proteolytic (网) bacteria. 